Type of the Paper (Article)

\title{
Evolution and antimicrobial resistance of enterococci isolated from Pecorino and goat cheese manufactured on-farm in an area facing constraints as per EU Regulation 1305/2013 in Um- bria, Italy.
}

\author{
Beniamino Cenci-Goga ${ }^{1,2^{*}}$, Musafiri Karama 2, Saeed El-Ashram ${ }^{3,4}$, Cristina Saraiva ${ }^{5,6}$, Juan García-Díez ${ }^{5}$, Athana- \\ sios Chalias ${ }^{7}$ and Luca Grispoldi ${ }^{1}$
}

1 Dipartimento di Medicina Veterinaria, Università degli Studi di Perugia, Italy;

beniamino.cencigoga@unipg.it

2 Faculty of Veterinary Science, Department of Paraclinical Sciences, University of Pretoria, Onderstepoort 0110, South Africa; musafiri.karama@up.ac.za

3 School of Life Science and Engineering, Foshan University, Foshan Guangdong 528231, China; saeed_elashram@yahoo.com

4 Faculty of Science, Kafrelsheikh University, Kafr el-Sheikh, 33516, Egypt; saeed elashram@ya$\underline{\text { hoo.com }}$

5 Veterinary and Animal Research Centre (CECAV). University of Trás-os-Montes e Alto Douro, 5001-801, Vila Real, Portugal; crisarai@utad.pt; juangarciadiez@utad.pt

6 Department of Veterinary Sciences, School of Agrarian and Veterinary Sciences, University of

Trás-os-Montes e Alto Douro, 5000-801. Vila Real, Portugal; crisarai@utad.pt

7 European Food Safety Authority, EU-FORA Programme, 43126 Parma, Italy; a.chalias@gmail.com

* Correspondence: Beniamino Cenci Goga; beniamino.cencigoga@unipg.it ; Tel.: +39 0755857973

\begin{abstract}
The latest EU regulation on geographical indications (EU Regulation No. 1151/2012) has introduced a set of new tools for the protection and enhancement of food products in rural areas, under the group name of optional quality term (OQT). The Commission Delegated EU Regulation, No. 665/2014, regulated the conditions for the use of the optional quality term «mountain product» (MP), to support the implementation of a mountain value chain. This new tool is aimed at promoting local development, maintaining the economic activities in mountain areas and redistributing wealth, whilst, at the same time, promoting the territory. Pecorino and goat cheeses are typical Italian cheeses made usually with whole raw ewe's or raw goat's milk, without starter culture addition. In an attempt to characterize these productions, the aim of this study was to investigate the evolution of enterococci during the production and ripening of Pecorino cheese made in three different farms, located in Umbria, Italy in areas facing natural or other specific constraints as stipulated by Regulation 1305/2013 on support for rural development by the European Agricultural Fund for Rural Development (EAFRD). Enterococci are enteric organisms which are commonly isolated from ewe and goat's milk production in Umbria, Italy. Counts of enterococci in raw milk ranged from 1.75 for ovine milk to 3.62 for ewe milk and a marked reduction was observed after thermization especially in ovine milk. Out of 100 isolates, 69 were E. faecium, 23 E. durans, 8 E. faecalis and 2 E. casseliflavus and the distribution of species between farms and between samples showed a prevalence of E. faecium in ovine farms and E. durans in ewes farms, with an equal distribution between samples. High percentages of susceptible isolates were found for amoxicillin/clavulanic acid, ampicillin, chloramphenicol, sulphamethoxazole, sulphamethoxazole/trimethoprim, ticarcillin, vancomycin. A high prevalence of resistant strains (> 30\%) was observed for amikacin, ciprofloxacin, ceftriaxone, kanamycin, tetracycline. A comparison of this results with those of previous works on similar dairy products revealed high levels of resistance to antimicrobials which needs to be addressed.
\end{abstract}

Keywords: Enterococcus, QPS, GRAS, safety, milk, cheese 


\section{Introduction}

One of the roles the EU covers is that of creating an equilibrium amongst the dimensions of governance, embedding, and marketing, in order to define policies and strategies to manage productive activities. One such activity is to define strategic choices for the promotion of European foodstuffs. In this context, the latest EU regulation on geographical indications (EU Regulation No. 1151/2012) has introduced a set of new tools for the protection and enhancement of food products in rural areas, under the group name of optional quality term (OQT). The Commission Delegated EU Regulation, No. 665/2014, regulated the conditions for the use of the optional quality term «mountain product» (MP), to support the implementation of a mountain value chain. This new tool aimed at promoting local development, maintaining the economic activities in mountain areas and redistributing wealth, whilst, at the same time, promoting the territory [1]. Umbria, Italy is a region with several areas facing natural or other specific constraints as stipulated by Regulation 1305/2013 on support for rural development by the European Agricultural Fund for Rural Development (EAFRD).

Pecorino and goat cheeses are typical cheeses produced in these areas, made usually with whole raw ewe's or raw goat's milk, without starter culture addition. Thus, only bacteria from milk contribute to ripening changes in the cheese [2]. Enterococci represent the predominant microbiota of these productions [2-7].

Enterococci are gram-positive bacteria and may fit within the general definition of lactic acid bacteria. With regard to safety and according to the Qualified Presumption of Safety (QPS) list from the European Food Safety Authority (EFSA) (https://www.efsa.europa.eu/en/topics/topic/qps), Enterococcus species are neither recommended for the QPS list [8] nor have GRAS (Generally Regarded As Safe) status [9], in spite of recent scientific knowledge allowing differentiation of commensal from pathogenic strains [10-12]. Modern classification techniques resulted, back in 1980s, in the transfer of some members of the genus Streptococcus, notably some of the Lancefield's group D streptococci, to the new genus Enterococcus [13]. Enterococci can be used as indicators of faecal contamination and have been implicated in outbreaks of foodborne illness. On the other hand, they have been ascribed a beneficial or detrimental role in foods [10-12]. In processed meats, enterococci may survive heat processing and cause spoilage, though in certain cheeses the growth of enterococci contributes to ripening and development of product flavour $[2,10]$. Some enterococci of food origin produce bacteriocins that exert anti-Listeria activity [14]. Enterococci are used as probiotics to improve the microbial balance of the intestine, or as a treatment for gastroenteritis in humans and animals $[11,12,15,16]$. On the other hand, enterococci have become recognized as serious nosocomial pathogens causing bacteraemia, endocarditis, urinary tract and other infections. This is in part explained by the resistance of some of these bacteria to most antibiotics that are currently in use [10]. Resistance is acquired by gene transfer systems, such as conjugative or nonconjugative plasmids or transposons. It appears that foods could be a source of vancomycin-resistant enterococci $[11,17,18]$.

Regardless these considerations Enterococci are commonly found in milk and cheese [19] and there are two divergent opinions about the presence of enterococci in cheese. One is that enterococci should be considered more suitable than other groups commonly used as indicators of unhygienic procedures in food processing and handling (e.g. Enterobacteriaceae). This is related to their high heat resistance and salt tolerance [20]. The other opinion is that enterococci have a possible contribution to the ripening of cheese due to their lipolytic, proteolytic and caseinolytic activities [21]. Moreover it has been suggested that enterococci contribute to flavour due to the attitude of produce acetoin, diacetyl and acetaldehyde [21]. 
In an attempt to characterize cheese production from a mountain area in Umbria, Italy, and define safety aspects, the aim of this work was to investigate the evolution of enterococci during the production and ripening of Pecorino cheese made in an area facing natural and specific constraints as per EU Regulation 1305/2013, with two different cheesemaking processes from sheep and ewe milk and characterize Enterococcus spp. isolates for antibiotic susceptibility all along the cheesemaking and ripening process.

\section{Materials and Methods}

\subsection{Study area}

The three farms are located in Umbria, Italy in an area that extends from latitude $42.977715^{\circ} \mathrm{N}$ to $43.227086^{\circ} \mathrm{N}$ and from longitude $12.141079^{\circ} \mathrm{E}$ to $12.310128^{\circ} \mathrm{E}$ (Figure 1 ). The area, partly hilly and mountainous and partly flat and fertile owing to the valley of the Tiber river, is separated from the central Apennines by the Tiber Valley ("Val Tiberina"). The thee farms are located in areas facing natural or other specific constraints as stipulated by Regulation 1305/2013 on support for rural development by the European Agricultural Fund for Rural Development (EAFRD). For the three farms, according to the cited Commission Delegated EU Regulation, No. 665/2014, most of the conditions for the use of the optional quality term «mountain product» $(\mathrm{MP})$, to support the implementation of a mountain value chain, are present and might be the base for a regional development for rural areas.

\subsection{General}

The experiment was carried out on three farms in Umbria, farm A, has 500 Sardinian ewes, farm B has 200 Sardinian ewes, farm C has 80 Saanen goats. In farm A and B milk is collected with a milking machine and automatically filtered before the cheesemaking. In farm $\mathrm{C}$ goats are hand milked and the milk is filtered through a linen cloth.

Milk from each farm was collected, analysed and subsequently used to produce Pecorino or goat cheese. On each farm two different cheesemaking processes were carried out from raw milk and from heat-treated milk to which the autochthonous cultures were added as a starter. Bacterial strains used in the formulation were: Lactococcus lactis ssp. lactis, reference strain n. 340; L. lactis ssp. lactis, strain n. 16; Lactobacillus casei ssp. casei, strain n. 208. The morphological, biochemical and physiological characterization, the growth curves at several temperatures, including refrigeration conditions, the acidifying activity and their ability to improve palatability of cheeses have been reported by the authors in previous papers [15,22-26].

Each cheesemaking was replicated three times. According to this experimental procedure there were 18 manufacturing processes: 9 from raw milk and 9 from heat-treated milk.

\subsection{Cheese manufacturing}

Cheese was made from ewes and goats milk obtained from both evening and morning milking. The main steps of cheesemaking process were: milk coagulation in a tinned copper vat occurred at $37^{\circ} \mathrm{C}$ within about 30' by adding liquid calf rennet (Lima, Perugia, Italy, titre 1:10.000). The curd was cut into nut-sized granules (10 to $20 \mathrm{~mm}$ ), then stirring for 5 minutes, heated at $42-43^{\circ}$. After a pause of 5 to 10 minutes the curd was put into frames (20 cm diameter by $8 \mathrm{~cm}$ high), pressed by hand for a few seconds, drained for 18 to 20 hours and salted in brine $\left(20 \% \mathrm{NaCl} \mathrm{w} / \mathrm{v}\right.$, at $12-15^{\circ} \mathrm{C}$ for $\left.30 \mathrm{~h}\right)$. The cheeses were ripened in non-conditioned storage rooms at $12-15^{\circ} \mathrm{C}$ and $83-87 \% \mathrm{RH}$ for 60 days (40 days for goat cheeses).

Heat treatment (where applied) included a heating step before the rennet addition. Raw milk was heated to $65-66^{\circ} \mathrm{C}$ for 3-4 min in a double wall stainless steel vat. The thermic cycle $55-65-55^{\circ} \mathrm{C}$ (during heating and cooling) took about $14 \mathrm{~min}$. After further cooling to $42{ }^{\circ} \mathrm{C}$, the starter was added at $42^{\circ} \mathrm{C}$ at a final concentration of $2 \%$ (as a full-coagulated $24 \mathrm{~h}$ culture in sterile milk)

\subsection{Sampling}


The following samples were taken on each farm: raw milk, heat-treated milk (where applied), curd, 7 days cheese, 30 days cheese, full-ripened cheese. Triplicate samples were collected, transported to the laboratory in chilled containers and analysed on the same day. Sampling was made according to ISO 5538:2004 [27].

\subsection{Bacterial counts}

The following groups were evaluated:

- total viable count: pour plates of Plate Count Agar (Difco, Detroit, Mi, USA), were incubated at $30^{\circ} \mathrm{C}$ for $72 \mathrm{~h}$; all colonies were counted;

- Enterobacteriaceae: pour plates of Violet Red Bile Agar (Difco) were incubated at $32^{\circ} \mathrm{C}$ for $48 \mathrm{~h}$; all pink to red colonies, irrespective of diameter or presence/absence of zone of precipitation were counted;

- enterococci: surface-inoculated plates of Barnes Agar (Biolife, Milano, Italy) were incubated at $44^{\circ} \mathrm{C}$ for $72 \mathrm{~h}$; all pink, red or maroon colonies, irrespective of diameter, were counted.

\subsection{Isolation and identification of enterococci}

Two to five colonies from each sample were sub-cultured from Barnes medium into brain heart infusion broth (BHI, Difco) at $37^{\circ} \mathrm{C}$ for $24 \mathrm{~h}$ and then tested for the following characteristics: cell morphology after Gram staining, presence of catalase, growth in bileesculin-azide agar (Coccosel agar, BioMérieux, Marcy-l'Etoile, France) at $37^{\circ} \mathrm{C}$, growth in $6.5 \% \mathrm{NaCl} \mathrm{BHI}$ agar (Difco) at $37^{\circ} \mathrm{C}$, growth in the presence of $4 \%$ bile salts (Coccosel agar, Biolife, with added $4 \%$ bile salts) at $37^{\circ} \mathrm{C}$, haemolysis type on tryptic soy agar (Biolife) to which $5 \%$ of ram blood was added, at $37^{\circ} \mathrm{C}$.

Complementary biochemical tests were performed on colonies grown on blood agar using the API 20 STREP (BioMérieux). Computer program Apiweb (BioMérieux) was used for the results.

\subsection{Antibiotics susceptibility}

Enterococcus spp. isolates were tested for antimicrobial susceptibility against a panel of 12 antimicrobials by the disk diffusion method (Kirby Bauer Test) as described by the Clinical and Laboratory Standards Institute [28] The following antimicrobials were tested: amikacin $30 \mathrm{mg}$, amoxicillin/clavulanic acid $30(20+10) \mathrm{mg}$, ampicillin $10 \mu \mathrm{g}$, ceftriaxone $30 \mu \mathrm{g}$, chloramphenicol $30 \mu \mathrm{g}$, ciprofloxacin $5 \mu \mathrm{g}$, kanamycin $30 \mu \mathrm{g}$, sulphamethoxazole 25 $\mu \mathrm{g}$, sulphamethoxazole/trimethoprim $25 \mu \mathrm{g}$, tetracycline $30 \mu \mathrm{g}$, ticarcillin $75 \mu \mathrm{g}$, vancomycin $30 \mu \mathrm{g}$. This antimicrobial panel was selected to test the major groups of antimicrobials. Briefly, frozen isolates were thawed and cultured in BHI broth (Bio-Rad) at 35 to $37^{\circ} \mathrm{C}$ for $24 \mathrm{~h}$. A portion of the culture broth was inoculated into $6 \mathrm{~mL}$ of $0.9 \%$ sterile physiological saline solution until a turbidity of $0.5 \mathrm{McFarland}$ was reached (1.0 for vancomycin [29]). Using a sterile swab, the solution was spread on Muller-Hinton agar plates (Oxoid). Antimicrobial disks (Oxoid) were placed on Muller-Hinton agar plates which were incubated at $37^{\circ} \mathrm{C}$ for 18 to $24 \mathrm{~h}$. At the end of incubation, the diameters of the growth inhibitory zones were measured, and these were interpreted using specific CLSI tables whereby the bacterium is classified as susceptible, intermediately susceptible or resistant [28].

\section{Results and discussion}

Results of the determination made on Pecorino and goat cheese during manufacture and ripening are given in tables 1-2-3-4-5-6.

Changes in total viable counts and Enterobacteriaceae.

The differences observed on the three farms comprised a range of variability which is common to on-farm cheesemaking (Table 1). 
Table 1. Evolution of microbiota during production and ripening of farm manufactured cheeses $\left(\log \mathrm{cfu} \mathrm{ml}^{-1} \mathrm{or} \mathrm{g}^{-1}, \mathrm{sd}\right.$ standard deviation.

\begin{tabular}{|c|c|c|c|c|c|c|}
\hline \multirow[b]{2}{*}{ Farm A - raw milk } & \multicolumn{2}{|c|}{ Aerobic viable count } & \multicolumn{2}{|c|}{ Enterobacteriaceae } & \multicolumn{2}{|c|}{ Enterococcus spp. } \\
\hline & mean & $\mathrm{sd}$ & mean & sd & mean & sd \\
\hline raw milk & 5.9 & 0.34 & 3.93 & 0.42 & 2.74 & 2.81 \\
\hline curd & 7.42 & 0.23 & 4.41 & 0.34 & 3.47 & 3.08 \\
\hline 1 week & 10.04 & 0.79 & 5.76 & 0.21 & 5.26 & 2.74 \\
\hline 1 month & 8.7 & 0.14 & 1.69 & 2.93 & 4.42 & 1.95 \\
\hline 2 months & 7.1 & 0.64 & 0.00 & 0.00 & 3.66 & 1.1 \\
\hline \multicolumn{7}{|c|}{ Farm A - heat treated milk } \\
\hline raw milk & 5.9 & 0.34 & 3.93 & 0.42 & 2.74 & 2.81 \\
\hline heat treated milk & 3.06 & 0.25 & 0.00 & 0.00 & 0.33 & 0.58 \\
\hline curd & 7.58 & 0.89 & 3.33 & 0.64 & 4.6 & 1.8 \\
\hline 1 week & 8.56 & 2.03 & 3.88 & 3.4 & 5.54 & 2.92 \\
\hline 1 month & 9.42 & 0.4 & 1.37 & 2.37 & 6.27 & 1.5 \\
\hline 2 months & 9.13 & 0.57 & 0.00 & 0.00 & 4.29 & 1.12 \\
\hline \multicolumn{7}{|l|}{ Farm B - raw milk } \\
\hline raw milk & 6.01 & 0.31 & 4.7 & 0.36 & 1.75 & 3.03 \\
\hline curd & 7.19 & 0.66 & 5.34 & 1.49 & 4.72 & 0.59 \\
\hline 1 week & 9.13 & 0.38 & 5.3 & 0.45 & 5.74 & 1.1 \\
\hline 1 month & 8.19 & 0.44 & 1.78 & 0.88 & 5.33 & 1.01 \\
\hline 2 months & 7.44 & 0.85 & 0.00 & 0.00 & 3.66 & 1.1 \\
\hline \multicolumn{7}{|c|}{ Farm B - heat treated milk } \\
\hline raw milk & 6.01 & 0.31 & 4.7 & 0.36 & 1.75 & 3.03 \\
\hline heat treated milk & 4.56 & 0.91 & 0.48 & 0.83 & 1.79 & 1.72 \\
\hline curd & 8.15 & 0.46 & 4.61 & 1.35 & 5.92 & 0.86 \\
\hline 1 week & 10 & 0.44 & 5.86 & 0.49 & 6.27 & 0.33 \\
\hline 1 month & 8.01 & 0.42 & 3.15 & 1.32 & 4.67 & 0.75 \\
\hline 2 months & 8.34 & 0.22 & 0.00 & 0.00 & 5.14 & 0.36 \\
\hline \multicolumn{7}{|l|}{ Farm C - raw milk } \\
\hline raw milk & 7.54 & 0.36 & 3.63 & 0.85 & 3.62 & 1.11 \\
\hline curd & 8.74 & 0.31 & 5.15 & 0.11 & 5.37 & 1.03 \\
\hline 1 week & 9.46 & 0.00 & 4.91 & 0.27 & 5.77 & 0.79 \\
\hline 1 month & 7.81 & 0.27 & 1.81 & 1.57 & 5.35 & 1.24 \\
\hline 2 months & 7.97 & 0.12 & 1.63 & 1.45 & 4.41 & 0.46 \\
\hline \multicolumn{7}{|c|}{ Farm C - heat treated milk } \\
\hline raw milk & 7.54 & 0.36 & 3.63 & 0.85 & 3.62 & 1.11 \\
\hline heat treated milk & 4.91 & 0.09 & 0.72 & 0.72 & 2.47 & 0.04 \\
\hline curd & 8.42 & 0.05 & 3.81 & 0.53 & 6.22 & 1.18 \\
\hline 1 week & 9.72 & 0.01 & 5.92 & 0.24 & 6.7 & 0.59 \\
\hline 1 month & 8.12 & 0.27 & 2.75 & 1.55 & 4.36 & 0.82 \\
\hline 2 months & 7.99 & 0.61 & 0.83 & 1.43 & 4.92 & 0.41 \\
\hline
\end{tabular}


The total mesophilic aerobes in raw milk ranged from $\log 5.9 \log \mathrm{cfu} \mathrm{ml}^{-1}$ in farm A to $\log 7.54 \log \mathrm{cfu} \mathrm{ml}^{-1}$ in farm C. At the early stage of production of cheeses made with raw milk, counts increased up to 1 week and then decreased. In the cheesemaking processes from heat-treated milk added with autochthonous starter cultures bacterial population in milk, after the treatment, was reduced to $\log 3.06 \log \mathrm{cfu} \mathrm{ml}^{-1}$ in farm A, $\log 4.56$ $\log \mathrm{cfu} \mathrm{ml}^{-1}$ in farm B and $\log 4.91 \mathrm{log} \mathrm{cfu} \mathrm{ml}^{-1}$ in farm C. After the treatment counts showed the same evolution described for cheeses made with raw milk.

Enterobacteriaceae in raw milk ranged from $3.9 \log \mathrm{cfu} \mathrm{ml}^{-1}$ in farm A to $3.9 \log \mathrm{cfu}$ $\mathrm{ml}^{-1}$ in farm B. In cheeses made with raw milk Enterobacteriaceae increased up to curd production and then decreased being not detectable or at low concentration at the end of the ripening. On farm $\mathrm{B}$ and $\mathrm{C}$ bacterial reduction was observed on 1-week cheese whilst on farm $\mathrm{A}$ an additional growth occurred in cheese during the first week of ripening, after which there was a decrease in population. Enterobacteriaceae were not detectable in fullripened cheese made with raw ewe's milk whilst they were detected from full-ripened cheese made with raw goat's milk. In cheeses made with heat-treated milk with added autochthonous starter cultures, Enterobacteriaceae underwent great reduction in heattreated milk being not detectable in farm $\mathrm{A}$, whilst they were only partially reduced in farm B and C (4.22 log of reduction in farm B and 2.91 in farm C). Although heavy curd recontamination always occurred, no Enterobacteriaceae were detectable in full-ripened cheese made with heat-treated ewe's milk, whilst they were still detected in cheeses made with heat-treated goat's milk.

Samelis, et al. [30] studied the changes in microbial composition of raw milk induced by thermization and demonstrated that the treatment significantly reduced bacterial populations of raw milk. Although the $67^{\circ} \mathrm{C}$ treatment was much more effective against all bacterial groups than was the $60^{\circ} \mathrm{C}$ treatment, the latter had major inactivation effects against gram-negative bacteria but moderate effects against gram-positive bacteria. Reductions in populations of thermophilic LAB, including enterococci, in samples thermized at $60^{\circ} \mathrm{C}$ were not significant.

\subsection{Behaviour of enterococci}

Enterococci counts in milk were always lower than $4 \log \mathrm{cfu} \mathrm{ml}^{-1}$. The changes observed were similar to those observed previously [2]. At the early stage of production of cheeses made with raw milk, counts increased up to 1 week and then slightly decreased. In the cheesemaking processes from heat-treated milk with added autochthonous starter cultures no evident reduction of enterococci population was observed after the treatment. After the heat treatment counts showed the same behaviour described for cheeses made with raw milk.

Other authors have studied Enterococcus spp. populations in pecorino and other traditional cheeses. For instance Serio, et al. [7] found that the presence of enterococci in Pecorino Abruzzese ranged from $\log 4 \mathrm{cfu} \mathrm{g}^{-1}$ to $\log 4 \mathrm{cfu} \mathrm{g}^{-1}$ at the beginning of ripening and reached $\log 9 \mathrm{cfu} \mathrm{g}^{-1}$ in ripened cheeses. Similar results were described by LitopoulouTzanetaki and Tzanetakis [4] which described enterococci levels in traditional Greek cheeses as ranging from $\log 6 \mathrm{cfu} \mathrm{g}^{-1}$ to $\log 10 \mathrm{cfu} \mathrm{g}^{-1}$ for the different kind of products examined.

\section{Identification}

One-hundred strains of enterococci were identified. Forty-six from farm A, thirtytwo from farm B and twenty-two from farm C. Sixty-nine were identified as Enterococcus faecium, twenty-two as Enterococcus durans, seven as Enterococcus faecalis and two as Enterococcus casseliflavus (Tables 2 and 3). Enterococcus faecium was found more frequently on farm A $(80.4 \%)$ and on farm B (68.8\%), whilst on farm C more than $95 \%$ of the isolates consisted of Enterococcus faecium and Enterococcus durans altogether. No strains of Enterococcus faecalis were found on Farm A, whilst Enterococcus casseliflavus was found only on farm B.

Recently, Russo, et al. [5] described the prevalence distribution of enterococci in Ragusano and Pecorino Siciliano: $35 \%$ of the isolate were ascribed to E. durans, 35\% to E. 
faecalis, $28 \%$ to E. faecium. Overall data from previous studies are quite similar and the prevalence of E. faecium/E. durans, followed by E. faecalis is reported quite constantly [3133].

Table 2. Distribution of Enterococcus spp. per sample.

\begin{tabular}{lllllll}
\hline Species & n. & milk & curd & 7-day cheese & 30-day cheese & full ripened cheese \\
\hline E. faecium & 69 & $8(5)$ & $4(8)$ & $10(6)$ & $4(5)$ & $10(9)$ \\
E. durans & 22 & $2(-)$ & $1(4)$ & $3(4)$ & $2(-)$ & $5(1)$ \\
E. faecalis & 8 & $-(-)$ & $1(-)$ & $1(-)$ & $-(-)$ & $5(-)$ \\
E. casseliflavus & 2 & $-(-)$ & $-(-)$ & $-(-)$ & $-(-)$ & $-(2)$ \\
\hdashline Total & 100 & $10(5)$ & $6(12)$ & $14(10)$ & $6(5)$ & $20(12)$ \\
\hline
\end{tabular}

( ) = cheesemaking processes from heat-treated milk.

Table 3. Distribution of Enterococcus spp. per farm.

\begin{tabular}{|c|c|c|c|c|c|c|c|c|}
\hline \multirow[t]{2}{*}{ Species } & \multicolumn{2}{|l|}{ n. } & \multicolumn{2}{|c|}{ Farm A } & \multicolumn{2}{|c|}{ Farm B } & \multicolumn{2}{|c|}{ Farm C } \\
\hline & n. & $\%$ & n. & $\%$ & n. & $\%$ & n. & $\%$ \\
\hline E. faecium & 69 & 69 & 37 & 80.4 & 22 & 68.8 & 10 & 45.4 \\
\hline E. durans & 22 & 22 & 9 & 19.6 & 2 & 6.2 & 11 & 50.0 \\
\hline E. faecalis & 7 & 7 & - & - & 6 & 18.8 & 1 & 4.6 \\
\hline E. casseliflavus & 2 & 2 & - & - & 2 & 6.2 & - & - \\
\hline Total & 100 & 100 & 46 & 100 & 32 & 100 & 22 & 100 \\
\hline
\end{tabular}

Bacterial cells under microscopic observation after Gram staining appeared Gram positive, in pairs or in short chains, ovoid elongated in direction of the chain. All strains were catalase negative. This result together with cells morphology confirmed the identification of the strains as belonging to the genus Streptococcus. Enterococci were identified as such on the basis of their growth in the presence of bile-esculin, $6.5 \%$ of $\mathrm{NaCl}$ solution, and $4 \%$ bile salts, and on the basis of the hydrolysis of the arginine. TTC reduction on Barnes medium differentiated E. faecalis from E. faecium. In fact, culture grown in the presence of triphenyl tetrazolium chloride (TTC) on Barnes medium were white or with a red centre and white border. The former was presumptively identified as E. faecium and the latter as E. faecalis prior to biochemical tests with API 20 Strep (BioMérieux). No strains were $B$-haemolytic.

The principal physiological and biochemical characteristics of the isolates are given on Table 4. 
Table 4. Principal physiological and biochemical characteristics of enterococci isolated from pecorino and goat cheese at various stages of ripening (figures are numbers of strains).

\begin{tabular}{lllll} 
& E. faecium & E. durans & E. faecalis & E. casseliflavus \\
\hline$\beta$-haemolysis & 0 & 0 & 0 & 0 \\
$\alpha$-haemolysis & 0 & 0 & 0 & 0 \\
$\gamma$-haemolysis & 69 & 22 & 7 & 2 \\
growth in bile-esculin & 69 & 22 & 7 & 2 \\
growth in the presence of $6.5 \% \mathrm{NaCl}$ & 69 & 22 & 7 & 2 \\
growth in the presence of $4 \%$ bile salts & 69 & 22 & 7 & 2 \\
growth in the presence of TTC & 69 & 22 & 7 & 2 \\
hydrolysis of arginine & 69 & 22 & 7 & 2 \\
hydrolysis of hippurate & 34 & 16 & 7 & 2 \\
acetoin production & 69 & 22 & 7 & 2 \\
fermentation of: & & & & 2 \\
$\quad$ mannitol & 69 & 0 & 7 & 0 \\
$\quad$ sorbitol & 0 & 0 & 7 & 2 \\
$\quad$ raffinose & 0 & 0 & 0 & 0 \\
$\quad$ inulin & 0 & 0 & 0 & 2 \\
$\quad$ L-arabinose & 68 & 0 & 0 & 2 \\
$\quad$ ribose & 69 & 22 & 7 & 2 \\
$\quad$ lactose & 69 & 22 & 7 & 2 \\
$\quad$ trehalose & 69 & 22 & 7 & 2 \\
$\quad$ starch & 68 & 16 & 7 & 0 \\
$\quad$ glycogen & 0 & 0 & 0 & 2 \\
Total number of strains & 69 & 22 & 7 & \\
\hline
\end{tabular}

\subsection{Antibiotics susceptibility}

The antimicrobial susceptibility test data are shown in Table 5 and 6. High percentages $(>80 \%)$ of susceptible strains were found for amoxicillin/clavulanic acid, ampicillin, chloramphenicol, sulphamethoxazole, sulphamethoxazole/trimethoprim, ticarcillin, vancomycin. A high prevalence of resistance strains (>30\%) was observed for amikacin, ciprofloxacin, ceftriaxone, kanamycin, tetracycline. It is important to note that $5 \%$ of the strains (one strain of E. durans and 4 strains of E. faecium all isolated from farm B) were resistant to vancomycin. In the last two decades, Enterococci have become major nosocomial pathogens. An increasing number of these infections are due to enterococci that are resistant to vancomycin. Accurate detection of vancomycin-resistant enterococci (VRE) is important so that appropriate therapy and infection control measures may be applied, including veterinary surveillance [34]. Russo, et al. [5] examined the susceptibility of Enterococcus spp. isolates to the most clinical antibiotics by microdilution method and found that $97 \%$ of the isolates, out of 110 , exhibited a multidrug-resistant phenotype (resistance to at least three antimicrobials) with 14 strains, $13 \mathrm{E}$. faecalis and one E. faecium, resistant to 7 out of 9 antimicrobials tested. Furthermore, 19 strains (15 E. durans, 2 E. faecalis and $2 \mathrm{E}$. faecium) showed resistance to 5 antimicrobials. In particular, out of $15 \mathrm{E}$. durans, all were resistant to erythromycin, 14 to rifampicin and ampicillin and 7 to penicillin. Only three (2.7\%) strains (E. durans, E. faecalis, and E. faecium) were susceptible to all tested antibiotics. These results highlighted the highest occurrence of resistance for rifampicin, erythromycin and ampicillin and the lowest for gentamicin. More recently Výrostková, et al. [35] reported that isolates of Enterococcus spp. showed high antibiotic resistance to vancomycin (84.62\%; 44/52 isolates), teicoplanin (84.62\%; 44/52 isolates), erythromycin (76.92\%; 40/52 isolates), and rifampicin (76.92\%; 40/52 isolates). Lower antibiotic resistance was detected against nitrofurantoin (46.15\%; $24 / / 52$ isolates) and minocycline (38.46\%; 20/52 isolates). Serio, et al. [7] analysed enterococci isolates from Pecorino 
Abruzzese and found a high incidence of antibiotic resistance, with a prevalence of erythromycin resistance especially for E. faecium (75.7\%), followed by E. faecalis (48.3\%), and E. durans $(37.5 \%)$. Results for vancomycin by disk diffusion test have been criticized and in 2011 the CLSI M100-S19 document has recommended the disuse of vancomycin disks for staphylococci and informed that studies on the action of teicoplanin in disk-diffusion testing should be performed [36], however, for screening purposes, such as in this study, the disk diffusion test is still a viable choice, especially for enterococci $[29,37]$. 
Table 5. Antimicrobial susceptibility data per Enterococcus spp.
Total $\mathrm{n}=100$
E. durans $\mathrm{n}=22$
E. faecium $\mathrm{n}=69$
E. faecalis $\mathrm{n}=7$
E. casseliflavus $\mathrm{n}=2$

\begin{tabular}{|c|c|c|c|c|c|c|c|c|c|c|c|c|c|c|}
\hline AK & $\underline{S}$ & I & $\mathrm{R}$ & $S$ & I & $\mathrm{R}$ & $\underline{S}$ & I & $\mathrm{R}$ & $\underline{S}$ & I & $\mathrm{R}$ & $\underline{S}$ & I \\
\hline total & 31 & 21 & 48 & 7 & 5 & 10 & 21 & 15 & 33 & 3 & 1 & 3 & 0 & 0 \\
\hline$\%$ & 31 & 21 & 48 & 31.8 & 22.7 & 45.5 & 30.4 & 21.7 & 47.8 & 42.9 & 14.3 & 42.9 & 0 & 0 \\
\hline $\begin{array}{l}\text { AMC } \\
\text { total }\end{array}$ & 99 & 1 & 0 & 22 & 0 & - & 68 & 1 & 0 & 7 & 0 & 0 & 2 & 0 \\
\hline$\%$ & 99 & 1 & 0 & 100 & 0 & - & 98.6 & 1.5 & 0 & 100 & 0 & 0 & 100 & 0 \\
\hline $\begin{array}{l}\text { AMP } \\
\text { total }\end{array}$ & 98 & 0 & 2 & 22 & 0 & 0 & 67 & 0 & 2 & 7 & 0 & 0 & 2 & 0 \\
\hline$\%$ & 98 & 0 & 2 & 100 & 0 & 0 & 97.1 & 0 & 2.9 & 100 & 0 & 0 & 100 & 0 \\
\hline 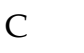 & & & & & & & & & & & & & & \\
\hline total & 94 & 5 & 1 & 22 & 0 & 0 & 63 & 5 & 1 & 7 & 0 & 0 & 2 & 0 \\
\hline$\%$ & 94 & 5 & 1 & 100 & 0 & 0 & 91.3 & 7.3 & 1.5 & 100 & 0 & 0 & 100 & 0 \\
\hline
\end{tabular}

CIP

$\begin{array}{llllllllllllllll}\text { total } & 23 & 47 & 30 & 8 & 9 & 5 & 15 & 29 & 25 & 0 & 7 & 0 & 0 & 2 & 0 \\ \% & 23 & 47 & 30 & 36.4 & 40.1 & 22.7 & 21.7 & 42.0 & 36.2 & 0 & 100 & 0 & 0 & 100 & 0\end{array}$

CRO

$\begin{array}{llllllllllllllll}\text { total } & 8 & 50 & 42 & 0 & 15 & 7 & 5 & 32 & 32 & 2 & 2 & 3 & 1 & 1 & 0 \\ \% & 8 & 50 & 42 & 0 & 68.2 & 31.8 & 7.3 & 46.4 & 46.4 & 28.6 & 28.6 & 42.9 & 50 & 50 & 0 \\ \mathrm{~K} & & & & & & & & & & & & & & & \\ \text { total } & 0 & 26 & 74 & 0 & 5 & 17 & 0 & 21 & 48 & 0 & 0 & 7 & 0 & 0 & 2 \\ \% & 0 & 26 & 74 & 0 & 22.7 & 77.3 & 0 & 30.4 & 69.6 & 0 & 0 & 100 & 0 & 0 & 100\end{array}$

RL

$\begin{array}{llllllllllllllll}\text { total } & 100 & 0 & 0 & 22 & 0 & 0 & 69 & 0 & 0 & 7 & 0 & 0 & 2 & 0 & 0 \\ \% & 100 & 0 & 0 & 100 & 0 & 0 & 100 & 0 & 0 & 100 & 0 & 0 & 100 & 0 & 0\end{array}$

SXT

$\begin{array}{llllllllllllllll}\text { total } & 89 & 4 & 7 & 19 & 0 & 3 & 62 & 4 & 3 & 6 & 0 & 1 & 2 & 0 & 0 \\ \% & 89 & 4 & 7 & 86.4 & 0 & 13.6 & 89.9 & 5.8 & 4.38 & 85.7 & 0 & 14.3 & 100 & 0 & 0\end{array}$

TE

$\begin{array}{llllllllllllllll}\text { total } & 45 & 16 & 39 & 13 & 3 & 6 & 27 & 11 & 31 & 4 & 2 & 1 & 1 & 0 & 1\end{array}$

$\begin{array}{llllllllllllllll}\% & 45 & 16 & 39 & 59.1 & 13.6 & 27.3 & 39.1 & 15.9 & 44.9 & 57.1 & 28.6 & 14.3 & 50 & 0 & 50\end{array}$

TIC

$\begin{array}{llllllllllllllll}\text { total } & 91 & 7 & 2 & 19 & 3 & 0 & 65 & 2 & 2 & 6 & 1 & 0 & 1 & 1 & 0\end{array}$ $\begin{array}{llllllllllllllll}\% & 91 & 7 & 2 & 86.4 & 13.6 & 0 & 94.2 & 2.9 & 2.9 & 85.7 & 14.3 & 0 & 50 & 50 & 0\end{array}$

VA

$\begin{array}{llllllllllllllll}\text { total } & 82 & 13 & 5 & 19 & 2 & 1 & 57 & 8 & 4 & 6 & 1 & 0 & 0 & 2 & 0\end{array}$

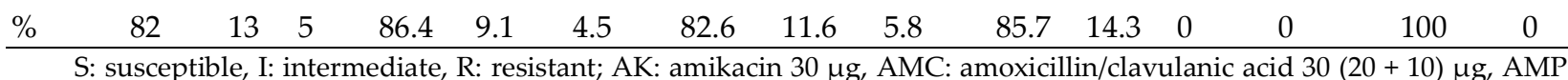
ampicillin $10 \mu \mathrm{g}$, C: chloramphenicol $30 \mu \mathrm{g}$, CIP: ciprofloxacin $5 \mu \mathrm{g}$, C RO: ceftriaxone $30 \mu \mathrm{g}$, K: kanamycin $30 \mu \mathrm{g}$, RL: sulphamethoxazole $25 \mu \mathrm{g}$, SXT: sulphamethoxazole/trimethoprim $25 \mu \mathrm{g}$, TE: tetracycline $30 \mu \mathrm{g}$, TIC: ticarcillin $75 \mu \mathrm{g}$, VA: vancomycin $30 \mu \mathrm{g}$. 
Table 6. Antimicrobial susceptibility data per farm.

\begin{tabular}{|c|c|c|c|c|c|c|c|c|c|c|c|c|}
\hline \multirow{4}{*}{$\begin{array}{l}\mathrm{AK} \\
\text { total } \\
\%\end{array}$} & \multicolumn{3}{|c|}{ total } & \multicolumn{3}{|c|}{ Farm A n $=46$} & \multicolumn{3}{|c|}{ Farm B n=32 } & \multicolumn{3}{|c|}{ Farm $C \mathrm{n}=22$} \\
\hline & $\mathrm{S}$ & $\mathrm{I}$ & $\mathrm{R}$ & $\mathrm{S}$ & I & $\mathrm{R}$ & $\mathrm{S}$ & I & $\mathrm{R}$ & $\mathrm{S}$ & I & $\mathrm{R}$ \\
\hline & 31 & 21 & 48 & 17 & 9 & 20 & 9 & 3 & 20 & 5 & 9 & 8 \\
\hline & 31 & 21 & 48 & 37.0 & 19.6 & 43.5 & 28.1 & 9.4 & 62.5 & 22.7 & 40.9 & 36.4 \\
\hline $\begin{array}{l}\mathrm{AMC} \\
\text { total }\end{array}$ & 99 & 1 & 0 & 46 & 0 & 0 & 31 & 1 & 0 & 22 & 0 & 0 \\
\hline & 99 & 1 & 0 & 100 & 0 & 0 & 96.9 & 3.1 & 0 & 100 & 0 & 0 \\
\hline $\begin{array}{l}\text { AMP } \\
\text { total } \\
\%\end{array}$ & $\begin{array}{l}98 \\
98\end{array}$ & $\begin{array}{l}0 \\
0\end{array}$ & $\begin{array}{l}2 \\
2\end{array}$ & $\begin{array}{c}46 \\
100\end{array}$ & $\begin{array}{l}0 \\
0\end{array}$ & $\begin{array}{l}0 \\
0\end{array}$ & $\begin{array}{c}30 \\
93.8\end{array}$ & $\begin{array}{l}0 \\
0\end{array}$ & $\begin{array}{c}2 \\
6.3\end{array}$ & $\begin{array}{c}22 \\
100\end{array}$ & $\begin{array}{l}0 \\
0\end{array}$ & $\begin{array}{l}0 \\
0\end{array}$ \\
\hline $\begin{array}{l}\mathrm{C} \\
\text { total } \\
\%\end{array}$ & $\begin{array}{l}94 \\
94\end{array}$ & $\begin{array}{l}5 \\
5\end{array}$ & $\begin{array}{l}1 \\
1\end{array}$ & $\begin{array}{c}45 \\
97.8\end{array}$ & $\begin{array}{l}0 \\
0\end{array}$ & $\begin{array}{c}1 \\
2.2\end{array}$ & $\begin{array}{c}27 \\
84.4\end{array}$ & $\begin{array}{c}5 \\
15.6\end{array}$ & $\begin{array}{l}0 \\
0\end{array}$ & $\begin{array}{c}22 \\
100\end{array}$ & $\begin{array}{l}0 \\
0\end{array}$ & $\begin{array}{l}0 \\
0\end{array}$ \\
\hline $\begin{array}{l}\text { CIP } \\
\text { total } \\
\%\end{array}$ & $\begin{array}{l}23 \\
23\end{array}$ & $\begin{array}{l}47 \\
47\end{array}$ & $\begin{array}{l}30 \\
30\end{array}$ & $\begin{array}{c}17 \\
37.1\end{array}$ & $\begin{array}{c}15 \\
32.6\end{array}$ & $\begin{array}{c}14 \\
30.4\end{array}$ & $\begin{array}{c}2 \\
6.3\end{array}$ & $\begin{array}{c}18 \\
56.3\end{array}$ & $\begin{array}{c}12 \\
37.5\end{array}$ & $\begin{array}{c}4 \\
18.2\end{array}$ & $\begin{array}{c}14 \\
63.6\end{array}$ & $\begin{array}{c}4 \\
18.2\end{array}$ \\
\hline $\begin{array}{l}\text { CRO } \\
\text { total } \\
\%\end{array}$ & $\begin{array}{l}8 \\
8\end{array}$ & $\begin{array}{l}50 \\
50\end{array}$ & $\begin{array}{l}42 \\
42\end{array}$ & $\begin{array}{c}2 \\
4.3\end{array}$ & $\begin{array}{c}15 \\
32.6\end{array}$ & $\begin{array}{c}29 \\
63.0\end{array}$ & $\begin{array}{c}6 \\
18.8\end{array}$ & $\begin{array}{c}19 \\
59.4\end{array}$ & $\begin{array}{c}7 \\
21.9\end{array}$ & $\begin{array}{l}0 \\
0\end{array}$ & $\begin{array}{c}16 \\
72.7\end{array}$ & $\begin{array}{c}6 \\
27.3\end{array}$ \\
\hline $\begin{array}{l}\mathrm{K} \\
\text { total } \\
\%\end{array}$ & $\begin{array}{l}0 \\
0\end{array}$ & $\begin{array}{l}26 \\
26\end{array}$ & $\begin{array}{l}74 \\
74\end{array}$ & $\begin{array}{l}0 \\
0\end{array}$ & $\begin{array}{c}16 \\
34.8\end{array}$ & $\begin{array}{c}30 \\
65.2\end{array}$ & $\begin{array}{l}0 \\
0\end{array}$ & $\begin{array}{c}7 \\
21.9\end{array}$ & $\begin{array}{c}25 \\
78.1\end{array}$ & $\begin{array}{l}0 \\
0\end{array}$ & $\begin{array}{c}3 \\
13.6\end{array}$ & $\begin{array}{c}19 \\
86.4\end{array}$ \\
\hline $\begin{array}{l}\mathrm{RL} \\
\text { total } \\
\%\end{array}$ & $\begin{array}{l}0 \\
0\end{array}$ & $\begin{array}{l}0 \\
0\end{array}$ & $\begin{array}{l}100 \\
100\end{array}$ & $\begin{array}{l}0 \\
0\end{array}$ & $\begin{array}{l}0 \\
0\end{array}$ & $\begin{array}{c}46 \\
100\end{array}$ & $\begin{array}{l}0 \\
0\end{array}$ & $\begin{array}{l}0 \\
0\end{array}$ & $\begin{array}{c}32 \\
100\end{array}$ & $\begin{array}{l}0 \\
0\end{array}$ & $\begin{array}{l}0 \\
0\end{array}$ & $\begin{array}{c}22 \\
100\end{array}$ \\
\hline $\begin{array}{l}\text { SXT } \\
\text { total } \\
\%\end{array}$ & $\begin{array}{l}89 \\
89\end{array}$ & $\begin{array}{l}4 \\
4\end{array}$ & $\begin{array}{l}7 \\
7\end{array}$ & $\begin{array}{c}43 \\
93.5\end{array}$ & $\begin{array}{l}0 \\
0\end{array}$ & $\begin{array}{c}3 \\
6.5\end{array}$ & $\begin{array}{c}26 \\
81.3\end{array}$ & $\begin{array}{c}4 \\
12.5\end{array}$ & $\begin{array}{c}2 \\
6.3\end{array}$ & $\begin{array}{c}20 \\
90.9\end{array}$ & $\begin{array}{l}0 \\
0\end{array}$ & $\begin{array}{c}2 \\
9.1\end{array}$ \\
\hline $\begin{array}{l}\mathrm{TE} \\
\text { total } \\
\%\end{array}$ & $\begin{array}{l}45 \\
45\end{array}$ & $\begin{array}{l}16 \\
16\end{array}$ & $\begin{array}{l}39 \\
39\end{array}$ & $\begin{array}{c}21 \\
45.7\end{array}$ & $\begin{array}{c}6 \\
13.0\end{array}$ & $\begin{array}{c}19 \\
41.3\end{array}$ & $\begin{array}{c}13 \\
40.6\end{array}$ & $\begin{array}{c}7 \\
21.9\end{array}$ & $\begin{array}{c}12 \\
37.5\end{array}$ & $\begin{array}{l}11 \\
50\end{array}$ & $\begin{array}{c}3 \\
13.6\end{array}$ & $\begin{array}{c}8 \\
36.4\end{array}$ \\
\hline $\begin{array}{l}\text { TIC } \\
\text { total } \\
\%\end{array}$ & $\begin{array}{l}91 \\
91\end{array}$ & $\begin{array}{l}7 \\
7\end{array}$ & $\begin{array}{l}2 \\
2\end{array}$ & $\begin{array}{c}46 \\
100\end{array}$ & $\begin{array}{l}0 \\
0\end{array}$ & $\begin{array}{l}0 \\
0\end{array}$ & $\begin{array}{c}27 \\
84.4\end{array}$ & $\begin{array}{c}3 \\
9.4\end{array}$ & $\begin{array}{c}2 \\
6.3\end{array}$ & $\begin{array}{c}18 \\
81.8\end{array}$ & $\begin{array}{c}4 \\
18.2\end{array}$ & $\begin{array}{l}0 \\
0\end{array}$ \\
\hline $\begin{array}{l}\text { VA } \\
\text { total } \\
\%\end{array}$ & $\begin{array}{l}82 \\
82\end{array}$ & $\begin{array}{l}13 \\
13\end{array}$ & $\begin{array}{l}5 \\
5\end{array}$ & $\begin{array}{c}43 \\
93.5\end{array}$ & $\begin{array}{c}3 \\
6.52\end{array}$ & $\begin{array}{l}0 \\
0\end{array}$ & $\begin{array}{c}18 \\
56.3\end{array}$ & $\begin{array}{c}9 \\
28.1\end{array}$ & $\begin{array}{c}5 \\
15.6\end{array}$ & $\begin{array}{c}21 \\
95.5\end{array}$ & $\begin{array}{c}1 \\
4.5\end{array}$ & $\begin{array}{l}0 \\
0\end{array}$ \\
\hline
\end{tabular}

S: susceptible, I: intermediate, R: resistant; AK: amikacin $30 \mu \mathrm{g}$, AMC: amoxicillin/clavulanic acid 30 (20 + 10) $\mu$ g, AMP: ampicillin $10 \mu \mathrm{g}$, C: chloramphenicol $30 \mu \mathrm{g}$, CIP: ciprofloxacin $5 \mu \mathrm{g}$, C RO: ceftriaxone $30 \mu \mathrm{g}$, K: kanamycin $30 \mu \mathrm{g}$, RL: sulphamethoxazole $25 \mu \mathrm{g}$, SXT: sulphamethoxazole/trimethoprim $25 \mu \mathrm{g}$, TE: tetracycline $30 \mu \mathrm{g}$, TIC: ticarcillin $75 \mu \mathrm{g}$, VA: vancomycin $30 \mu \mathrm{g}$.

\section{Conclusion}

The results clearly supported the technological and hygienic reasons that cheese processors have for applying mild thermization rather than typical pasteurization treatments in raw ewe's and goat's milk intended for use in traditional hard cheese processing. In principle, empirically applied thermization treatments should contribute to the reduction 
of the total microbial load of raw milk to levels assuring an optimal fermentation and increased safety of the resultant cheese while selecting for the beneficial part of the natural milk flora that maintains viability. Thermization of raw milk samples at $56^{\circ} \mathrm{C}$ for $30 \mathrm{~s} \mathrm{prac}-$ tically eliminated undesirable Enterobacteriaceae. In our previous study we demonstrated thermization of ewe's and goat's milk almost completely eliminated the coliforms and staphylococci in farm goat cheese, although these bacteria were present in high concentrations in raw milk. S. aureus strains (10\% of total staphylococci) were isolated from raw milk cheese samples only [2,38].

Regarding the antimicrobial susceptibility, in Turkey a study by Sanlibaba and Senturk [39] in 215 traditional cheese samples identified 99.1\% enterococcal isolates that were highly resistant to nalidixic acid (100\%), kanamycin (98.6\%), and rifampicin (78.4\%), and were resistant to ampicillin, ciprofloxacin, erythromycin, tetracycline, penicillin $\mathrm{G}$, chloramphenicol, gentamycin, and streptomycin [39]. On the other hand, according to Hollenbeck and Rice [40] the resistance profile of Enterococcus species according was as follows: erythromycin $(49.2 \%)$; vancomycin $(37.3 \%)$; and tetracycline $(45.8 \%)$. Concurrently, the detected occurrence of antibiotic resistance genes in theses tested enterococci was: ermA $44.8 \%$, vanA $63.6 \%$, tet $\mathrm{A} 51.9 \%$, tetM $55.6 \%$, ermB $13.8 \%$, and vanB $22.7 \%$. This study may reveal that RTE food products may be reservoirs of detectable enterococci such as E. casseliflavus, E. durans, E. hirae, E. gallinarum.

Also Serio, et al. [7] found a high incidence of antibiotic resistance, with a prevalence of erythromycin resistance especially for E. faecium (75.7\%), followed by E. faecalis (48.3\%), and E. durans (37.5\%). Food isolates resistant to this macrolide have been reported by other authors, such as Russo, et al. [5], but in lower percentages and with a higher incidence for E. faecalis than for E. faecium. The widespread erythromycin resistance could be related to the presence in enterococci of plasmids and transposons [41].

Our results, with an overall high level of resistance of Enterococcus spp. to erythromycin (48\% of the strains), ciprofloxacin (30\%), ceftriaxone $(42 \%)$, kanamycin $(74 \%)$ and tetracycline $(39 \%)$, including a $5 \%$ of the strains resistant to vancomycin (and $13 \%$ intermediate) demonstrated that the resistance to antimicrobial of Enterococcus spp. is distributed over a wide variety of antibiotics groups. According to Werner, et al. [18] the genomic composition of enterococci, their robust nature, the frequent occurrence in many natural habitats and their flexibility to respond to varying environmental conditions make them a central hub (a «drug resistance gene trafficker») for resistance gene acquisition, conservation and dissemination, especially among related Gram-positive bacteria

In Pecorino and goat cheese the ripening processes are the result of the natural microbiological contamination of milk and of the characteristics cheesemaking technology. Therefore, not only lactic acid bacteria but also other bacterial groups, such as enterococci, must be considered. This study demonstrated that, regardless the cheesemaking technology, heavy curd recontamination occurs and that enterococci are always detected at high concentration at the end of ripening. A large proportion of isolates are also resistant to antibiotics and this pose the question whether microorganism belonging to Enterococcus spp. should be awarded in future the QPS or GRAS status.

The development of mountain farming and the promotion of mountain food production are a way to encourage sustainable development of mountain areas, which are generally considered places with specific geographic and climatic constraints. In order to promote strategies for mountain products, the European Union with the Regulation (EU) No 1151/2012 reserves the use of the term "Mountain Product" to food products produced and processed in mountain areas. This regulation was supplemented by the Delegated Act (EU) No 665/2014, which specifies the conditions of use of the optional quality term "Mountain Product". It is of the utmost importance to assess the interest in the application of the new mountain label and the perception of the food mountain products by the Umbria Region. However, we believe that the creation of a label to protect and certify mountain food could be the basis to improve the promotion of mountain quality food products and the sustainability of these areas 
Author Contributions: “Conceptualization, B.C.G. and L.G.; methodology, B.C.G. and L.G.; formal analysis, B.C.G. and L.G.; writing - original draft preparation, B.C.G.; writing-review and editing, B.C.G., M.K., S.E.S.; supervision, C.S. and J.G.D..; project administration, B.C.G.; funding acquisition, B.C.G. All authors have read and agreed to the published version of the manuscript."

Funding: "This research was funded by EFSA, European Food Safety Authority, grant number GP/EFSA/ENCO/2018/05_GA6".

Acknowledgments: The authors express sincere appreciation to members of Polyglot, Perugia, Italy, for a careful reading and comments on the manuscript.

Conflicts of Interest: "The authors declare no conflict of interest."

\section{References}

1. Bonadonna, A.; Peira, G.; Giachino, C.; Molinaro, L. Traditional Cheese Production and an EU Labeling Scheme: The Alpine Cheese Producers' Opinion. Agriculture 2017, 7, doi:10.3390/agriculture7080065.

2. Clementi, F.; Cenci-Goga, B.; Trabalza Marinucci, M.; Di Antonio, E. Use of selected starter cultures in the production of farm manufactured goat cheese from thermized milk. Italian Journal of Food Science 1998, 10, 41-56.

3. Cenci-Goga, B.; Clementi, F.; Di Antonio, E. Behaviour of lactic and non lactic microflora during production and ripening of on-farm manufactured Pecorino cheese. 1995, 219-235.

4. Litopoulou-Tzanetaki, E.; Tzanetakis, N. Microbiological characteristics of Greek traditional cheeses. Small Ruminant Research 2011, 101, 17-32, doi:https://doi.org/10.1016/j.smallrumres.2011.09.022.

5. Russo, N.; Caggia, C.; Pino, A.; Coque, T.M.; Arioli, S.; Randazzo, C.L. Enterococcus spp. in Ragusano PDO and Pecorino Siciliano cheese types: A snapshot of their antibiotic resistance distribution. Food and Chemical Toxicology 2018, 120, 277-286, doi:https://doi.org/10.1016/j.fct.2018.07.023.

6. Serio, A.; Chaves-López, C.; Paparella, A.; Suzzi, G. Evaluation of metabolic activities of enterococci isolated from Pecorino Abruzzese cheese. International Dairy Journal 2010, 20, 459-464, doi:10.1016/j.idairyj.2010.02.005.

7. Serio, A.; Paparella, A.; Chavez-López, C.; Corsetti, A.; Suzzi, G. Enterococcus populations in pecorino abruzzese cheese: Biodiversity and safety aspects. Journal of Food Protection 2007, 70, 1561-1568, doi:10.4315/0362-028X-70.7.1561.

8. Hazards, E.Panel o.B. Scientific Opinion on the update of the list of QPS-recommended biological agents intentionally added to food or feed as notified to EFSA. EFSA Journal 2017, 15, e04664, doi:https://doi.org/10.2903/j.efsa.2017.4664.

9. Huys, G.; Botteldoorn, N.; Delvigne, F.; De Vuyst, L.; Heyndrickx, M.; Pot, B.; Dubois, J.-J.; Daube, G. Microbial characterization of probiotics-Advisory report of the Working Group "8651 Probiotics" of the Belgian Superior Health Council (SHC). Molecular Nutrition \& Food Research 2013, 57, 1479-1504, doi:https://doi.org/10.1002/mnfr.201300065.

10. Dapkevicius, M.D.; Sgardioli, B.; Câmara, S.P.A.; Poeta, P.; Malcata, F.X. Current Trends of Enterococci in Dairy Products: A Comprehensive Review of Their Multiple Roles. Foods 2021, 10, doi:10.3390/foods10040821.

11. Graham, K.; Stack, H.; Rea, R. Safety, beneficial and technological properties of enterococci for use in functional food applications - a review. Critical Reviews in Food Science and Nutrition 2020, 60, 3836-3861, doi:10.1080/10408398.2019.1709800.

12. Hanchi, H.; Mottawea, W.; Sebei, K.; Hammami, R. The Genus Enterococcus: Between Probiotic Potential and Safety Concerns-An Update. Frontiers in Microbiology 2018, 9, 1791.

13. Schleifer, K.H.; Kilpper-Bälz, R. Transfer of Streptococcus faecalis and Streptococcus faecium to the Genus Enterococcus nom. rev. as Enterococcus faecalis comb. nov. and Enterococcus faecium comb. nov. International Journal of Systematic and Evolutionary Microbiology 1984, 34, 31-34, doi:https://doi.org/10.1099/00207713-34-1-31.

14. Franz, C.M.A.P.; Van Belkum, M.J.; Holzapfel, W.H.; Abriouel, H.; Gálvez, A. Diversity of enterococcal bacteriocins and their grouping in a new classification scheme. FEMS Microbiology Reviews 2007, 31, 293-310, doi:10.1111/j.15746976.2007.00064.x. 
15. Cenci-Goga, B.T.; Karama, M.; Sechi, P.; Iulietto, M.F.; Novelli, S.; Selvaggini, R.; Mattei, S. Growth Inhibition of Selected Microorganisms by an Association of Dairy Starter Cultures and Probiotics. Italian Journal of Animal Science 2015, 14, 3745, doi:10.4081/ijas.2015.3745.

16. Grispoldi, L.; Giglietti, R.; Traina, G.; Cenci-Goga, B. How to Assess in vitro Probiotic Viability and the Correct Use of Neutralizing Agents. Frontiers in Microbiology 2020, 11, 204.

17. Cenci-Goga, B.T.; Crotti, S.; Costarelli, S.; Rondini, C.; Karama, M.; Bennett, P. Detection of tet(M) Gene from Raw Milk by Rapid DNA Extraction Followed by a Two-Step PCR with Nested Primers. Journal of Food Protection 2004, 67, 2833-2838, doi:10.4315/0362-028X-67.12.2833.

18. Werner, G.; Coque, T.M.; Franz, C.M.A.P.; Grohmann, E.; Hegstad, K.; Jensen, L.; van Schaik, W.; Weaver, K. Antibiotic resistant enterococci-Tales of a drug resistance gene trafficker. International Journal of Medical Microbiology 2013, 303, 360379, doi:https://doi.org/10.1016/j.ijmm.2013.03.001.

19. Tsanasidou, C.; Asimakoula, S.; Sameli, N.; Fanitsios, C.; Vandera, E.; Bosnea, L.; Koukkou, A.-I.; Samelis, J. Safety Evaluation, Biogenic Amine Formation, and Enzymatic Activity Profiles of Autochthonous Enterocin-Producing Greek Cheese Isolates of the Enterococcus faecium/durans Group. Microorganisms 2021, 9, doi:10.3390/microorganisms 9040777.

20. Sojeong, H.; Jungmin, L.; Jong-Hoon, L.; Do-Won, J. Genomic Insight into the Salt Tolerance of Enterococcus faecium, Enterococcus faecalis, Tetragenococcus halophilus. J. Microbiol. Biotechnol. 2019, 29, 1591-1602, doi:10.4014/jmb.1908.08015.

21. Marilley, L.; Casey, M.G. Flavours of cheese products: metabolic pathways, analytical tools and identification of producing strains. International Journal of Food Microbiology 2004, 90, 139-159, doi:https://doi.org/10.1016/S0168-1605(03)00304-0.

22. Cenci-Goga, B.T.; Karama, M.; Sechi, P.; Iulietto, M.F.; Grispoldi, L.; Selvaggini, R.; Ceccarelli, M.; Barbera, S. Fate of selected pathogens in spiked «SALAME NOSTRANO» produced without added nitrates following the application of NONIT ${ }^{\mathrm{TM}}$ technology. Meat Science 2018, 139, 247-254, doi:https://doi.org/10.1016/j.meatsci.2018.02.002.

23. Cenci-Goga, B.T.; Karama, M.; Sechi, P.; Iulietto, M.F.; Novelli, S.; Selvaggini, R.; Barbera, S. Effect of a novel starter culture and specific ripening conditions on microbiological characteristics of nitrate-free dry-cured pork sausages. Italian Journal of Animal Science 2016, 15, 358-374, doi:10.1080/1828051X.2016.1204633.

24. Sechi, P.; Iulietto, M.F.; Mattei, S.; Traina, G.; Codini, M.; Cenci-Goga, B.T. In vitro activity of a formulation of lactic acid bacteria of dairy origin and probiotics vs. selected pathogens. 2014, 185, 82-82.

25. Sechi, P.; Iulietto, M.F.; Mattei, S.; Traina, G.; Codini, M.; Cenci-Goga, B.T. Effect of a formulation of selected dairy starter cultures and probiotics on microbiological, chemical and sensory characteristics of swine dry-cured sausages. 2014, 185, 8383.

26. Cenci-Goga, B.T.; Rossitto, P.V.; Sechi, P.; Parmegiani, S.; Cambiotti, V.; Cullor, J.S. Effect of selected dairy starter cultures on microbiological, chemical and sensory characteristics of swine and venison (Dama dama) nitrite-free dry-cured sausages. Meat Science 2012, 90, 599-606, doi:https://doi.org/10.1016/j.meatsci.2011.09.022.

27. ISO CH. ISO 5538:2004 [IDF 113:2004] Milk and milk products - Sampling - Inspection by attributes. 2004.

28. CLSI. M100. Performance Standards for Antimicrobial Susceptibility Testing, 31st Edition. Clinical and Laboratory Standards Institute (CLSI), Wayne,PA. 2021.

29. Wongthong, S.; Dutchanutouch, K.; Namsaengkang, V.; Chanawong, A.; Wilailuckana, C.; Lulitanond, A. Performance of vancomycin and teicoplanin disk diffusion test in isogenic vancomycin non-susceptible Staphylococcus aureus. J Infect Dev Ctries 2015, 9, 157-164, doi:10.3855/jidc.5059.

30. Samelis, J.; Lianou, A.; Kakouri, A.; DelbÈS, C.; Rogelj, I.; BogoviČ-MatijaŠIĆ, B.; Montel, M.-C. Changes in the Microbial Composition of Raw Milk Induced by Thermization Treatments Applied Prior to Traditional Greek Hard Cheese Processing. Journal of Food Protection 2009, 72, 783-790, doi:10.4315/0362-028X-72.4.783. 
31. Andrighetto, C.; Knijff, E.D.O.; Lombardi, A.; Torriani, S.; Vancanneyt, M.; Kersters, K.; Swings, J.; Dellaglio, F. Phenotypic and genetic diversity of enterococci isolated from Italian cheeses. Journal of Dairy Research 2001, 68, 303-316, doi:10.1017/S0022029901004800.

32. Jamet, E.; Akary, E.; Poisson, M.-A.; Chamba, J.-F.; Bertrand, X.; Serror, P. Prevalence and characterization of antibiotic resistant Enterococcus faecalis in French cheeses. Food Microbiology 2012, 31, 191-198, doi:https://doi.org/10.1016/j.fm.2012.03.009.

33. Templer, S.P.; Baumgartner, A. Enterococci from Appenzeller and Schabziger raw milk cheese: antibiotic resistance, virulence factors, and persistence of particular strains in the products. J Food Prot 2007, 70, 450-455, doi:10.4315/0362-028x70.2.450.

34. European Centre for Disease Prevention Control. Surveillance of antimicrobial resistance in Europe 2018. 2019.

35. Výrostková, J.; Regecová, I.; Dudriková, E.; Marcinčák, S.; Vargová, M.; Kováčová, M.; Malová, J. Antimicrobial Resistance of Enterococcus sp. Isolated from Sheep and Goat Cheeses. Foods 2021, 10, doi:10.3390/foods10081844.

36. Camargo, C.H.; Mondelli, A.L.; Bôas, P.J.F.V. Comparison of teicoplanin disk diffusion and broth microdilution methods against clinical isolates of Staphylococcus aureus and S. epidermidis. Braz J Microbiol 2011, 42, 1265-1268, doi:10.1590/S151783822011000400003.

37. Hegstad, K.; Giske, C.G.; Haldorsen, B.; Matuschek, E.; Schønning, K.; Leegaard, T.M.; Kahlmeter, G.; Sundsfjord, A.; Nordic, A.S.T.V.R.E.D.S.G. Performance of the EUCAST disk diffusion method, the CLSI agar screen method, and the Vitek 2 automated antimicrobial susceptibility testing system for detection of clinical isolates of Enterococci with low-and mediumlevel VanB-type vancomycin resistance: a multicenter study. J Clin Microbiol 2014, 52, 1582-1589, doi:10.1128/JCM.03544-13.

38. Avellini, P.; Clementi, F.; Marinucci, M.; Cenci-Goga, B.; Rea, S.; Branciari, R.; Cavallucci, C.; Reali, C.; Di Antonio, E. "Pit" cheese: Compositional, microbiological and sensory characteristics. Italian Journal of Food Science 1999, 11, $317-333$.

39. Sanlibaba, P.; Senturk, E. Prevalence, characterization and antibiotic resistance of enterococci from traditional cheeses in Turkey. International Journal of Food Properties 2018, 21, 1955-1963, doi:10.1080/10942912.2018.1489413.

40. Hollenbeck, B.L.; Rice, L.B. Intrinsic and acquired resistance mechanisms in enterococcus. Virulence 2012, 3, 421-569, doi:10.4161/viru.21282.

41. Foulquié Moreno, M.R.; Sarantinopoulos, P.; Tsakalidou, E.; De Vuyst, L. The role and application of enterococci in food and health. International Journal of Food Microbiology 2006, 106, 1-24, doi:https://doi.org/10.1016/j.ijfoodmicro.2005.06.026.

1. 